Serious English-speaking students of Central American archæology must know the writings of the distinguished German scholars whose names appear in Bulletin 28 under review; but even they will be glad to have these scattered papers translated for more convenient reference and collected in one volume. Other students who like to know what is being discovered in this region will be very thankful to Mr. Bowditch for his enterprise and labour in translating these papers, and to the Smithsonian Institution for placing all this material at their disposal in so convenient a form. On the whole, these papers will be of most value to those who concern themselves with the chronology and history of the Central American peoples; but there is a great deal to interest the general ethnologist, though he will have to search for his material, as most of it is scattered all over the volume in diverse papers. Particularly interesting in this respect are the papers on "Zapotec Priesthood and Ceremonials," "Deities and Religious Conceptions of the Zapotecs," and "Comparative Studies in the Field of Maya Antiquities "; the last paper deals with the clothing, personal decoration, and utensils of the Mayas as illustrated in the manuscripts, or on the monuments or other remains. According to a widespread tradition, the Toltecs were the originators of all arts and sciences; and the invention of the calendar is ascribed to them, and we are informed they carried their book with them on their migrations. The calendar is the fount of the Central American sacerdotal wisdom, and the great mass of Mexican and Maya manuscripts is nothing more than an elaboration of this calendric system in respect to its numerical theory, its chronology, and its system of divination. The book is copiously illustrated, and altogether it will form a most welcorne addition to the working library of various kinds of students of archæology and ethnology.

Mr. Swanton gives literal translations of a number of Haida folk-tales obtained on the Queen Charlotte Islands, British Columbia; this careful piece of work will be much appreciated by folklorists.

When one looks at the bulk of ethnological matter published by the United States Government, and realises the enormous value to students of these full, accurate, and well-illustrated memoirs, one cannot but feel ashamed of our Government, which, possessing every opportunity and inducement to study and report upon our own native races, does absolutely nothing.

A. C. HADDON.

\section{THE EDUCATION AND TRAINING OF THE} ENGINEER.

FNGINEERING in its various branches takes so E large and important a part in the industrial activities of modern nations that no pains are too great which will secure for our engineers a suitable and adequate school and college training, supplemented by a judiciously organised scheme of practical work in the shops and drawing office. More especially is this the case in this country, where, owing to the satisfaction which has followed previous success, manufacturers have been insufficiently alive to the fact that for many years other nations have been steadily building up efficient schemes of technical and professional education at the cost of much enterprise and greater self-sacrifice, with the natural result that our supremacy, long undisputed in these spheres of industry, has been undermined, and in some degree wrested from us.

It is for reasons such as these that the investigations inaugurated and carried out under the auspices of the Institution of Civil Engineers, the results of which are embodied in a recent report on the education and training of engineers, are to be welcomed. In November, rgo3, the council of the Institution appointed a committee to consider and report as to the best methods of training for all classes of engineers, including both scholastic and subsequent technical education, it being a'l instruction of the council that the principle was to be maintained that the education of an engineer must include both practical experience and scientific training. The constitution of the committee was completed in February, 1904, and owing to the wisdom and breadth of outlook of the council of the Institution of Civil Engineers, accredited representatives of the various institutions of mechanical, electrical, gas, and mining engineers, naval architects, shipbuilders, and others were added to the committee, which under the able chairmanship of Sir William White, K.C.B., F.R.S., was soon actively at work.

The inquiry, which has extended over more than two years, proceeded under the following sections: (1) Preparatory education in secondary schools; (2) training in offices, workshops, factories, or on works; (3) training in universities and higher technical institutions; (4) post-graduate work. The investigations under the first heading were entrusted to a subcommitee, while the committee as a whole undertook the consideration of the questions arising under the remaining three sections. The inquiries of the committee have been prosecuted by obtaining, sometimes orally though generally by correspondence, the opinions of teachers and professors with experience in engineering education, and of eminent engineers practising in various branches of the profession. The ultimate result is that, though diversities of opinion have been disclosed in regard to some details, yet, in all the main features of its recommendations, the committee has support from the great majority of professional engineers as well as of the professors of engineering subjects in our universities and higher technical institutions.

\section{Preparatory Education.}

The subcommittee, entrusted with the work of ascertaining the views of authorities competent to speak concerning the most suitable form of secondary education for boys destined to become engineers, issued a schedule of questions to 120 representative teachers in engineering colleges, headmasters of secondary schools devoting special attention to scientific training, and engineers not engaged in teaching. The queries raised in the schedule dealt with such points as the proper age for leaving school, the desirability of a leaving examination for secondary schools, the extent and methods of the teaching-suitable for future engineers-in English subjects, languages, mathematics, science, drawing, and surveying. The schedule of questions raised, in addition, the important subject as to how far schoolboys should have, as a school exercise, practice in ordinary handicraft work, such as carpentry or turning; and to what extent it has been found better to make all " practical" work into laboratory exercises in science. Replies were reccived from 80 per cent. of the gentlemen whose opinions were invited, and from these definite conclusions were deduced as to the prevailing opinion on the points raised in the schedule of questions. These conclusions were embodied in a report of the subcommittee, which was eventually approved and adopted by the main committee. The following recommendations are the outcome of the exhaustive inquiry.

A boy intended for the engineering profession should, before leaving school and commencing to specialise, have attained a standard of education equivalent to that recognised by universities for matriculation 
purposes. His special training should not commence until he is about seventeen years of age. To ensure such a standard of efficiency a leaving examination for secondary schools is desirable throughout the United Kingdom, so that there may be no room for doubt as to whether a boy has received a satisfactory preliminary education.

Advanced teaching of history and geography, with instruction and practice in essay-writing and in préciswriting, should be included in the ordinary school curriculum; and the instruction in English subjects should include at least an introduction to English literature.

Greek should not be required, but an elementary knowledge of Latin is desirable. The study of Latin should, however, be discontinued during the last two years of attendance at school, or after the standard required for the leaving certificate has been attained. Modern languages, especially French and German, should be studied, and should be taught colloquially or in such a way as to give the pupils a practical knowledge of each language, sufficient to enable them to study its literature and to converse in it with some degree of facility.

Instruction in mathematics should be given by methods differing considerably from those usually adopted in the teaching of this subject merely as an intellectual exercise. The geometrical side of mathematics should be fostered, and before they leave school boys should be conversant with the use of logarithms, and with at least the elements of trigonometry. Instruction in practical arithmetic should be carried further than has been generally the case hitherto, with the object especially of encouraging the use of contracted methods and of encouraging also the expression of results with only such a degree of accuracy as is consistent with the known degree of certainty of the data on which the calculations are based.

It is preferable that boys should attain at school a general knowledge of physics and chemistry rather than that they should pursue in detail some particular branch of science. Special attention should be given to drawing. Work in the nature of handicraft, such as carpentry or turning, may be encouraged as a recreation, but should not be required as a school exercise.

The committee very properly recommends that the scheme of education outlined in its report should be communicated officially to the Board of Education and be circulated widely amongst those responsible for the work in secondary schools and engineering colleges. The importance of the committee's recommendations, indeed, cannot be overestimated. Educational experts have long foreseen the impossibility of securing a rational system of secondary education in the absence of a carefully planned investigation to determine precisely what secondary education has to accomplish and how the desired end may best be reached. The Institution of Civil Engineers has by its public-spirited action shown schoolmasters the way so far as the reducation of future engineers is concerned. Here is the opportunity for which earnest educators have been looking. The ground to be covered has been carefully mapped out by experts, and we at last know precisely what is required of the secondary school so far as training engineers is concerned. It is earnestly to be hoped that the opportunity will not be lost. If for the next ten years these judicious recommendations could be made the basis of the secondary education provided for all boys intended for engineering, and if the results of following the scheme could be accurately recorded during this period, we should in I9 6 be in possession of data which would bring us within easy distance of formulating with confidence a course of school study No. I 906, voL. 74] which would provide engineers with boys trained in such a way as to make their future rational development easy and straightforward.

\section{EngineERING Training.}

It was eventually decided by the committee to deal together with the sections of its inquiry concerned with training in offices, workshops, factories, or on works ; training in universities and higher technical institutions; and post-graduate work. As in the case of the investigation dealing with the school career of the future engineer, so in this case a schedule of questions was framed and circulated widely. But a modification was introduced; the committee embodied in the schedule certain conclusions on important subjects on which it was unanimous. At the same time a free expression of divergent opinions was invited.

In the schedule of opinions and questions the committee expressed its opinion that the age for leaving school of the future engineer should be seventeen years, and seventy per cent. of the 267 engineers and others who sent replies expressed agreement with this proposal. The opinion of the committee that it is desirable that the course of training for all branches of engineering should include at least one year's training in mechanical engineering workshops, where, ordinarily, information would be gained of the practical applications of electricity, was endorsed by 72 per cent. of those who responded to the invitation of the committee to express their views, and $2 \mathrm{I}$ per cent. considered this period too short. There was, however, far less unanimity as to when this introductory workshop course should be taken. The committee laid it down that the course should be taken at an early period-either previously to the commencement of college training, or after that portion of the college training which is common to all branches of engineering has been completed. Thirty-three per cent. of the responding referees merely expressed agreement with the committee, while 47 per cent. were definite that it should be before the college training began.

Four-fifths of the replies received agreed with the committee that during the introductory workshop course, and indeed in subsequent similar courses, boys should keep the regular working hours, be treated like ordinary apprentices, and be paid wages. Rather more than half the referees replying thought boys should be expected to attend evening classes during this workshop course, and 35 per cent. thought educational work should be suspended during this time. A large majority of the replies showed that it is generally considered desirable that this workshop course should be followed by a period of study in a technical college or university before specialisation in particular branches of engineering .is undertaken, and that the period of college study should be arranged so as to alternate with the practical training.

There was great diversity of opinion as to what constitutes a reasonable total period of practical training on works, in factories, workshops, mines, and so on-apart from the introductory workshop course. Thirty per cent. of the replies mention three years, twenty per cent. give two years, and the remaining opinions vary from one to five years. The committee recommends a total period of four years inclusive of the introductory workshop course. On the other hand, it seemed to be generally agreed that the scale on which appliances and equipment for instructing engineering students should be provided in technical colleges should be limited only by the funds at the disposal of the college authorities.

The three concluding opinions formulated by the committee on the schedule distributed met with general approval. It is considered desirable, in con- 
nection with the grant of degrees, diplomas, and certificates to engineering students, that great importance should be attached to laboratory and experimental work performed by individual students, as well as to their progress in mathematical and scientific studies, rather than that degrees and so on should be granted on the results of terminal or final examinations. It is urged that facilities for post-graduate work by engineering students in higher technical institutions should be much increased; and it is admitted by almost all authorities that the improvements of engineering education depend greatly on the attitude of employers towards the recommendations made by the committee, and employers are urged to extend the facilities to engineering students for post-graduate study and research.

The recommendations of the committee in respect of engineering training embody the conclusions arrived at by an examination of the replies just summarised, and it is unnecessary to do more than point out the respects in which the recommendations amplify the opinions set forth in the schedule prepared for distribution. The recommendation respecting the introductory workshop course explained above recognises that at present there are practical difficulties in arranging for this workshop year being interposed between the school and college work, and that employers may consider the arrangement detrimental to their interests. The committee suggests, however, that these difficulties should not be insurmountable, and the general agreement as to its advantageous effect on training leads it to hope that practical trial may be given to the plan.

Concerning attendance at evening classes during the introductory workshop course, the committee thinks it is most important that all boys should at least maintain their scholastic acquirements, and it is considered that this result might be secured, by private tuition or otherwise, without undue physical strain. So, too, the general recommendation that the introductory workshop course should be followed immediately by attendance at college is modified. It is stated that in some cases-as, for example, when boys are intended to become mechanical engineers--it may be advantageous to complete the practical training before entering college; but, if this is done, private tuition or evening classes must be the rule during the years of practical work.

The longest of the recommendations urges the need for a sound and extensive knowledge of mathematics ia all branches of engineering. The committee endorses the practically universal opinion that a sufficient time should be allotted to the study of pure mathematics during the common college course, and that the extent to which individual students can be carried in mathematics must be decided by the teachers.

Such are, in brief, the more important of the committee's recommendations, and it is interesting to compare these with some aspects of American practice. The rule in the engineering courses of the colleges of the United States, which it must be remembered always follow a prolonged secondary education, is that in the first two years of the course-which generally lasts four years-a fair amount of time is given to mathematics, English, modern languages, and experimental science, and it is chiefly in the workshop and drawing office that the specialisation towards engineering is apparent during these years. Specialisation begins to show itself prominently during the third year, and mechanical technology and electrotechnics are more or less taken up in the mechanical and electrical engineering courses. In the fourth year a crowd of engineering subjects is frequently introduced. But as Prof. Ripper remarks in his Mosely Commission report, " From the English standpoint too much importance may be attached to prolonged literary training, and not enough importance to the practical training of students during the earlier years of their career, nor to the cultural value of a scientific and professional education." But in no respect are American conditions more different from those at home than in the attitude of the employers of labour toward higher education. As Dr. Walmsley has testified in a recent report (see NATURE, vol. 1xx., p. 23r), "Without exception the officials interviewed asserted that, far from having any difficulty in placing the graduates turned out year by year from the engineering courses, for the last few years the graduate class has had every one of its individual members engaged for remunerative work before the completion of the course at college."

Such are the importance of the report of the Institution of Civil Engineers and the care which has been expended upon its preparation, that it is to be hoped it will be read alike by all responsible for the educa. tion of our future engineers, and by those who are in a position to employ the young men when their training is complete. In face of the severe competition between nations for industrial supremacy, it becomes a national duty for each and all, who can assist and forward the means of preparing the men in whose care our manufactures and general mercantile welfare will rest, to do their best; and a debt of gratitude is due to the Institution of Civil Engineers for the work it has accomplished.

A. T. S.

BALLOONS AND KITES IN THE SERVICE OF METEOROLOGY.

DURING recent years a considerable amount of information has been accumulated about the conditions which prevail in the higher strata of the atmosphere. Although observations of temperature and humidity were made by Glaisher from a free balloon more than fifty years ago, and later Mr. Archibald used kites to determine the change of wind velocity with elevation, it is only in the last ten years that a systematic attempt has been inaugurated to obtain information. There is now a fair amount of observational material awaiting someone with the necessary skill and leisure to work it up, and it is much to be hoped that the task may be taken in hand shortly, so that the results obtained in various countries and by various organisations or individuals may be arranged and coordinated, in order that further inquiry may be pushed along the most promising lines.

The means of observation available are practically kites and small unmanned balloons carrying selfrecording instruments, aided to some extent by direct observations made from manned balloons; and the only obstacle to continuous daily or even hourly readings at moderate heights is that of expense.

The free balloons possess the advantages of reaching heights unattainable by any other means, and of being independent of weather conditions. Either paper or rubber balloons are used of about six to ten feet diameter. These balloons are filled with hydrogen, and carry up with them a self-recording meteorograph made as light as possible; they frequently reach heights exceeding ten miles, and it is seldom, at least on the more thickly inhabited parts of the Continent, such as France and Germany, that they are lost. Each balloon carries an attached label offering a small reward to the finder, and the address to which information is to be sent, and in general the meteorograph is recovered with its record in a decipherable condition within a few weeks or a month. It is desirable that the balloon should fall as near as possible to its starting point, and with a rubber balloon this

NO I906, vOL. 74] 